

Scand J Work Environ Health 1987;13(5):438-444

https://doi.org/10.5271/sjweh.2016

Issue date: Oct 1987

Hydrocarbon exposure from handling jet fuel at some Swedish aircraft units.

by Holm S, Norback D, Frenning B, Gothe CJ

Affiliation: Department of Occupational Medicine, Sodersjukhuset, Stockholm, Sweden.

This article in PubMed: www.ncbi.nlm.nih.gov/pubmed/3433046

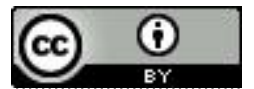




\title{
Hydrocarbon exposure from handling jet fuel at some Swedish aircraft units
}

\author{
by Stina Holm, BA, ${ }^{1}$ Dan Norbäck, BA, ${ }^{2}$ Bertil Frenning, MD, ${ }^{2}$ Carl-Johan Göthe, $\mathrm{MD}^{1}$
}

\begin{abstract}
HOLM S, NORBÄCK D, FRENNING B, GÖTHE C-J. Hydrocarbon exposure from handling jet fuel at some Swedish aircraft units. Scand $J$ Work Environ Health 13 (1987) 438-444. The exposure to vapors from jet fuel under different work conditions was examined in three aircraft squadrons. Exposure measurements were made by charcoal sampling in the breathing zones of 23 randomly selected employees belonging to three different personnel groups. Each person was followed during two consecutive days by long-time sampling and, furthermore, by 15-minute sampling during work operations with possible high exposure. The charcoal tubes were eluted with carbon disulfide, and the hydrocarbons were analyzed with gas chromatography. The geometric mean of both the long- and the short-time exposure was only $1-2 \%$ of the corresponding occupational exposure limits. The highest long-time exposure observed was about $25 \%$ of the occupational exposure limit, while the highest short-time exposure was about $130 \%$ of the corresponding limit. Thus the present long-term exposure to solvent vapor in Swedish aircraft units is low, but infrequent short-time exposure above the present limit may occur in some work operations.
\end{abstract}

Key terms: aircraft, benzene, gas chromatography, hexane, isopropyl nitrate, jet fuel, occupational, solvents.

Jet fuel (MC-77) is a mixture of aliphatic and aromatic hydrocarbons with a boiling point interval of $50-300^{\circ} \mathrm{C}$ and a vapor pressure of $19.6 \mathrm{kPa}$ at $37^{\circ} \mathrm{C}$. According to the manufacturers, the content of benzene and n-hexane is less than $1 \%$ (weight/weight). MC-77 has been used by the Swedish Armed Forces since 1956.

There have been some reports on the toxic effects of long-time exposure to jet fuel on the central and peripheral nervous systems $(2,3,4,5,11)$, but only sparse information on the average exposures is found in the literature. In a study by Knave et al (3) some figures on short-time exposures during specific work conditions are given. Some unpublished studies of the exposure to jet fuel have also been done in the Swedish Air Force, but these studies were mainly restricted to specific work operations of short duration. No information has been found on 8-h measurements of jet fuel exposure.

The objective of the present study was to determine the present total exposure to volatile hydrocarbons from jet fuel and solvents in the Swedish Armed Forces. It was paralleled by a study of the health status of military personnel exposed to the fuel (to be published).

1 Department of Occupational Medicine, Södersjukhuset, Stockholm, Sweden.

2. Department of Occupational Medicine, Akademiska sjukhuset, Uppsala, Sweden.

Reprint requests to: Dr C-J Göthe, Department of Occupational Medicine, Södersjukhuset, S-100 64 Stockholm, Sweden.

\section{Materials and methods}

Three units of the Swedish National Defence were studied. Two of them (A and B) were fighter squadrons with similar organizations and types of activities. They differed however concerning the type of aircraft used. The third unit (C) was a naval helicopter squadron using two types of machines.

Jet fuel exposure can occur in different types of work, eg, in jet fuel handling, in routine servicing of aircraft before flight, and in regular service of the aircraft and engines in the service workshops. Jet fuel handling includes transporting fuel, filling field and supply tanks, draining these tanks, and servicing pump units. Every day before the flights the aircraft are serviced and, among other things, their fuel tanks are filled and checked for water content. The aircraft are regularly taken into the workshop for service. This work varies depending on how many hours the machine has been in use, but parts of the fuel system are always checked. When a total overhaul of the engine is done, the engine is removed from the aircraft and, in many cases, "preserved," ie, the jet fuel in the system is replaced by mineral oil with low volatility.

The different types of work have been divided into three groups, namely, the jet fuel handling group, the flight service group, and the workshop service group (including workshop service on aircraft and engines). Apart from jet fuel, the examined personnel were sometimes exposed to isopropyl nitrate (starter fuel) and to other solvents used for cleaning, for painting, and for leakage tests. The additional exposure from such solvents has been studied by comparison between mixed-solvent exposure including jet fuel and exposure to jet fuel alone. 
The measurements were made on arbitrarily chosen persons during two consecutive days (table 1) of, according to the personnel, ordinary activities. Four halfday samples were taken for at least one person in every personnel group from each unit. In addition, one 15-min sample (short-time sample) of the expected highest exposure was taken each day for each person. Outdoor and indoor temperatures and the relative humidities were measured with an Assman psychrometer (table 1).

Personal sampling with activated charcoal as the adsorbent was applied, the air sampling rate being 20 $\mathrm{ml} / \mathrm{min}$ for half-day samples and $200 \mathrm{ml} / \mathrm{min}$ for short-time samples. The charcoal tubes were kept at $-20^{\circ} \mathrm{C}$ until the day of the analysis.

The analysis was performed on a gas chromatograph (Hewlett Packard model 5880) equipped with a flame ionization detector and a capillary column with the following conditions: column: fused silica coated with methyl silicone fluid, $12 \mathrm{~m}$, inner diameter $0.2 \mathrm{~mm}$; carrier gas: helium $0.40 \mathrm{ml} / \mathrm{min}$, make-up flow 20 $\mathrm{ml} / \mathrm{min}$, split ratio $1: 60$; temperature: injector and detector $250^{\circ} \mathrm{C}$, oven initial $38^{\circ} \mathrm{C}$ for $2 \mathrm{~min}$, program rate $10^{\circ} \mathrm{C} / \mathrm{min}$, final $150^{\circ} \mathrm{C}$. Prior to the gas chromatographic analysis, volatile hydrocarbons were eluted from the charcoal with $4 \mathrm{ml}$ of carbon disulfide.

Curves were calibrated for 22 major hydrocarbons in jet fuel at five different concentrations. When uncalibrated peaks were being quantified, the mean response factor of the 22 standards was used. Splitless injection gave a higher sensitivity, but the wide peak of carbon disulfide covered some of the hydrocarbons with low boiling points $\left(<100^{\circ} \mathrm{C}\right.$, low boiling compounds). To be able to identify and quantify this fraction, we also analyzed the samples with a total hydrocarbon concentration of more than $5 \mathrm{mg} / \mathrm{m}^{3}$ with the split injection technique. For samples with a lower total concentration, the concentrations of the lowboiling compounds were estimated from the relation between the concentrations of the low-boiling compounds and the total concentration of compounds with boiling points above $100^{\circ} \mathrm{C}$ (high-boiling compounds) in samples analyzed with both the split and splitless injection techniques (table 2).

The present Swedish occupational exposure limit (1984) for jet fuel is $380 \mathrm{mg} / \mathrm{m}^{3}$ for the time-weighted average (TWA) concentration for a whole workday (8-h) and $500 \mathrm{mg} / \mathrm{m}^{3}$ for the short-time exposure limit (STEL) time weighted over $15 \mathrm{~min}$ (7).

As recommended for environmental samples (6), geometric means and geometric standard deviations have been used in the statistical calculations. In the tests with two samples drawn from the same sample population, the Mann-Whitney rank correlation test was used for calculating a two-sided P-value (9). The standard error of the analytical method (SE) has been calculated from the formula:

$$
\mathrm{SE}=\left\{\left[\Sigma \mathrm{d}^{2}-(\Sigma \mathrm{d})^{2} / \mathrm{n}\right] /[2(\mathrm{n}-1)]\right\} 1 / 2,
$$

where $\mathrm{d}=$ the difference between duplicate analyses and $\mathrm{n}=$ number of duplicate analyses.

The error of the analytical method, given as a percentage of the mean value of all the duplicate analyses, was 16.1 (SD 1.9) \% for the splitless injection technique and $6.6 \%$ (SD 1.4) \% for the split injection technique. The detection limits for the different compounds were $0.60 \mu \mathrm{g} / \mathrm{sample}$ and $10 \mu \mathrm{g} / \mathrm{sample}$ for the respective techniques.

Table 1. Sampling data.

\begin{tabular}{|c|c|c|c|c|c|c|c|}
\hline \multirow{3}{*}{ Unit } & \multirow{3}{*}{$\begin{array}{l}\text { Date of } \\
\text { measurement }\end{array}$} & \multirow{3}{*}{$\begin{array}{c}\text { Test } \\
\text { persons } \\
(\mathrm{N})\end{array}$} & \multirow{3}{*}{$\begin{array}{l}\text { Exposed } \\
\text { persons } \\
\text { (N) }\end{array}$} & \multicolumn{4}{|c|}{ Climate factors } \\
\hline & & & & \multicolumn{2}{|c|}{ Indoors } & \multicolumn{2}{|c|}{ Outdoors } \\
\hline & & & & $\begin{array}{c}\text { Temperature } \\
\left({ }^{\circ} \mathrm{C}\right)\end{array}$ & $\begin{array}{c}\text { Relative } \\
\text { humidity (\%) }\end{array}$ & $\begin{array}{c}\text { Temperature } \\
\left({ }^{\circ} \mathrm{C}\right)\end{array}$ & $\begin{array}{l}\text { Relative hu- } \\
\text { midity (\%) }\end{array}$ \\
\hline A & November 1983 & 10 & 63 & $17-22$ & $9-17$ & $-7--5$ & - \\
\hline $\mathrm{B}$ & September 1984 & 8 & 109 & $17-23$ & $47-54$ & $9-14$ & $80-95$ \\
\hline $\mathrm{C}$ & April 1984 & 5 & 21 & $16-22$ & $18-25$ & $8-10$ & $28-38$ \\
\hline
\end{tabular}

Table 2. Regression values of compounds with boiling points of less than $100^{\circ} \mathrm{C}$. These values have been used to calculate concentrations in samples not analyzed with the split-injection technique. $\left[\log _{10}\left(C_{c o m p}\right)=K^{*} \log _{10}\left(C_{h b c}\right)+L^{a}\right]$

\begin{tabular}{lccccc}
\hline $\begin{array}{l}\text { Compound } \\
\text { (of figure 2) }\end{array}$ & $\mathrm{N}$ & $\begin{array}{c}\text { Intercept } \\
\text { L }\end{array}$ & $\begin{array}{c}\text { Slope } \\
\text { K }\end{array}$ & $\begin{array}{c}\text { Standard deviation } \\
\text { of slope }\end{array}$ & $\begin{array}{c}\text { Correlation } \\
\text { coefficient }\end{array}$ \\
\hline A. n-Pentane & 6 & -1.48 & 1.47 & 0.29 & 0.93 \\
B. n-Hexane & 19 & -1.68 & 1.51 & 0.23 & 0.85 \\
C. Benzene & 33 & -1.37 & 0.85 & 0.13 & 0.75 \\
D. Cyclohexane & 38 & -1.35 & 1.02 & 0.11 & 0.83 \\
E. Uncalibrated compounds with & 23 & -0.59 & 0.96 & 0.22 & 0.68 \\
$\quad$ boiling point $<100^{\circ} \mathrm{C}$ & 23 & -13 & & 0.22 \\
\hline
\end{tabular}

a $\mathrm{C}_{\text {comp }}=$ concentration, exceeding $0.01 \mathrm{mg} / \mathrm{m}^{3}$, of each compound; $C_{h b c}=$ total concentration, exceeding $1 \mathrm{mg} / \mathrm{m}^{3}$, of hydrocarbons with boiling points $\geq 100^{\circ} \mathrm{C}$. 


\section{Results}

The distribution of the concentrations of the highboiling compounds in different samples was skew. As demonstrated in figure 1 , the logarithmic values were also somewhat skew, although to a considerably less degree. However, there were significant correlations between the logarithmic values of the concentrations of various low-boiling compounds and the logarithmic values of the sum of the high-boiling compounds

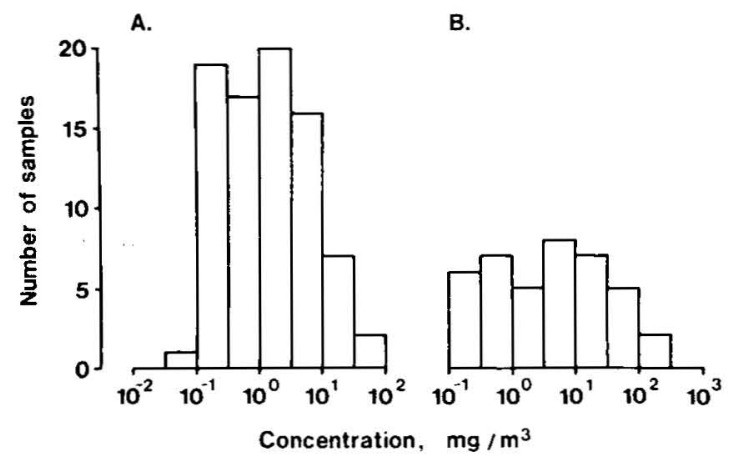

Figure 1. Frequency distribution of the concentrations of highboiling compounds from jet fuel in half-day samples (A) and short-time samples (B). in samples analyzed with both the splitless and split injection techniques (table 2 and figure 2). The correlation coefficients were of the magnitude $0.7-0.9$.

A typical chromatogram of jet fuel vapor is shown in figure 3. The airborne concentrations of the different calibrated compounds, as well as the estimated concentrations of the uncalibrated compounds, are presented in table 3 . The mean exposures were low, and none of the single compounds exceeded a geometric mean value of $0.4 \mathrm{mg} / \mathrm{m}^{3}$, but considerably higher peak values were found. $\mathrm{n}$-Hexane and n-pentane gave the highest maximum concentrations of the single compounds in both the half-day and short-time samples.

The maximum TWA exposure to hydrocarbons was $93 \mathrm{mg} / \mathrm{m}^{3}$, all samples being less than $50 \%$ of the 8 -h TWA. In most cases ( 86 out of 92 samples), the exposure was even less than $10 \%$ of the 8-h TWA. Measurements of short-time exposure showed only one of the 46 short-time samples $(2 \%)$ exceeding the present 15 -min STEL, and 36 of them $(78 \%)$ were less than $10 \%$ of the 15 -min STEL.

The differences between the examined work units were not significant in regard to short-time exposure. In unit A, however, some of the hangars had unsatisfactory ventilation, and the half-day exposure in this unit was significantly higher $(\mathrm{P}<0.001)$ than in the
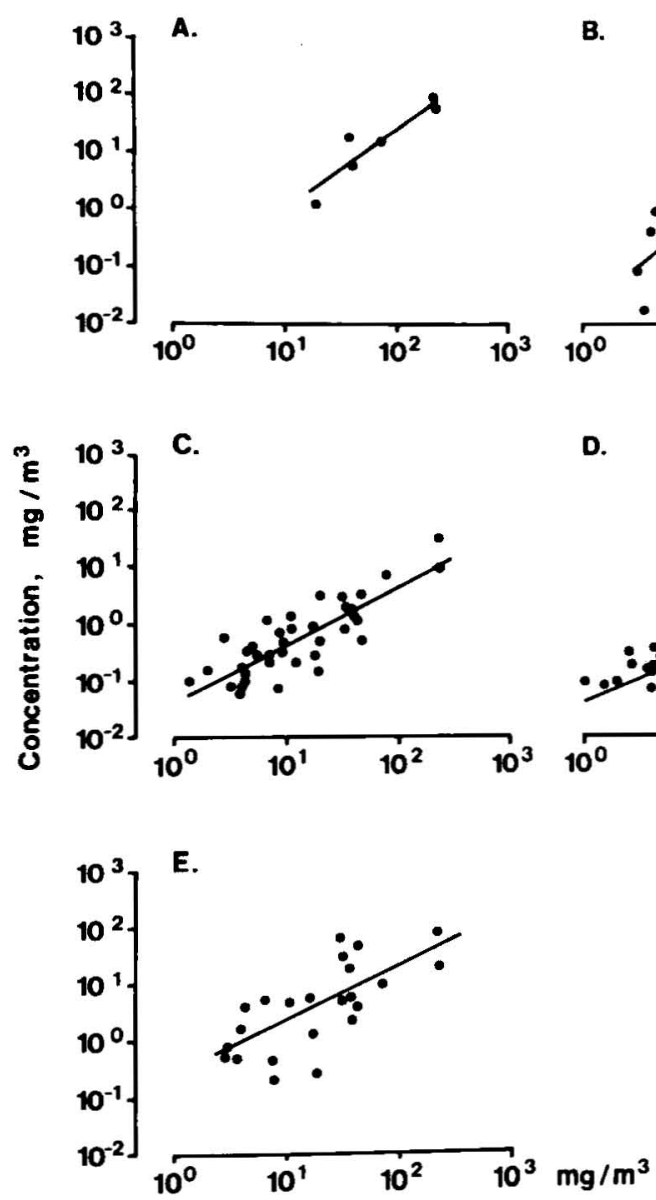

B.

D.
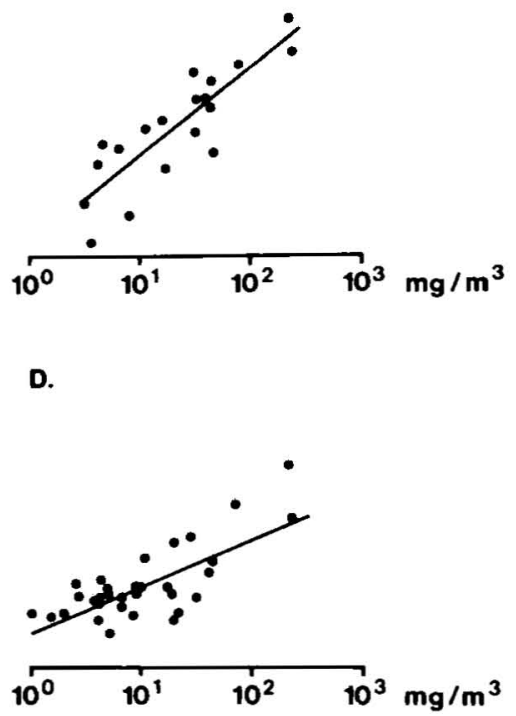

Figure 2. The concentration of different compounds analyzed with the split injection technique in relation to the total concentration of high-boiling compounds in the same sample analyzed with the splitless injection technique. Concentrations of the low boiling compounds in samples analyzed only with the splitless injection technique were calculated from the regressions presented in table 2 . ( $\mathrm{A}=$ n-pentane, $\quad \mathrm{B}=\mathrm{n}$-hexane, $\mathrm{C}=$ cyclohexane, $\mathrm{D}=$ benzene, $\mathrm{E}=$ uncalibrated low-boiling compounds) 




Figure 3. A typical chromatogram of jet fuel vapor.

Table 3. Airborne concentrations, $\mathrm{mg} / \mathrm{m}^{3}$, of compounds from half-day and short-time samples.

\begin{tabular}{|c|c|c|c|c|c|c|}
\hline & \multicolumn{3}{|c|}{ Half-day samples $(N=92)$} & \multicolumn{3}{|c|}{ Short-time samples $(\mathrm{N}=46$ ) } \\
\hline & $\begin{array}{l}\text { Maximum } \\
\text { value }\end{array}$ & $\begin{array}{l}\text { Geometric } \\
\text { mean }\end{array}$ & $\begin{array}{l}\text { Geomet- } \\
\text { ric SD }\end{array}$ & $\begin{array}{l}\text { Maximum } \\
\text { value }\end{array}$ & $\begin{array}{c}\text { Geometric } \\
\text { mean }\end{array}$ & $\begin{array}{l}\text { Geomet- } \\
\text { ric SD }\end{array}$ \\
\hline n-Pentane & 17.9 & 0.09 & 8.3 & 107 & 0.35 & 16.3 \\
\hline $\mathrm{n}$-Hexane & 28.8 & 0.05 & 7.1 & 157 & 0.17 & 13.8 \\
\hline Benzene & 7.2 & 0.06 & 4.0 & 39.4 & 0.14 & 6.8 \\
\hline Cyclohexane & 7.5 & 0.05 & 4.6 & 34.1 & 0.16 & 9.7 \\
\hline iso-Octane & 2.6 & 0.03 & 4.9 & 9.2 & 0.09 & 9.2 \\
\hline $\mathrm{n}$-Heptane & 14.8 & 0.14 & 7.3 & 38.8 & 0.35 & 12.3 \\
\hline Toluene & 6.8 & 0.07 & 6.6 & 70.6 & 0.22 & 12.3 \\
\hline n-Octane & 6.9 & 0.11 & 6.6 & 24.5 & 0.36 & 11.4 \\
\hline Ethylbenzene & 1.3 & 0.02 & 3.8 & 8.0 & 0.07 & 9.7 \\
\hline $\mathrm{m}$-Xylene + p-Xylene & 2.4 & 0.06 & 5.6 & 25.2 & 0.20 & 10.8 \\
\hline o-Xylene & 3.1 & 0.03 & 5.1 & 23.8 & 0.08 & 9.6 \\
\hline n-Nonane & 6.2 & 0.09 & 6.5 & 47.2 & 0.25 & 10.7 \\
\hline \multirow{2}{*}{\multicolumn{7}{|c|}{ 1,3-Ethylmethylbenzene + }} \\
\hline & 0.7 & 0.02 & 2.8 & 2.7 & 0.03 & 5.2 \\
\hline Mesitylene & 0.4 & 0.01 & 2.5 & 2.9 & 0.02 & 4.8 \\
\hline 1,2-Ethylmethylbenzene & 0.5 & 0.01 & 2.4 & 0.9 & 0.02 & 4.2 \\
\hline Pseudocumene & 1.7 & 0.03 & 4.0 & 11.7 & 0.05 & 7.6 \\
\hline n-Decane + hemimellitene & 6.5 & 0.10 & 7.1 & 36.4 & 0.17 & 10.3 \\
\hline n-Undecane & 4.9 & 0.07 & 6.8 & 18.6 & 0.11 & 9.2 \\
\hline n-Dodecane & 3.0 & 0.03 & 5.4 & 19.8 & 0.03 & 6.7 \\
\hline \multicolumn{7}{|l|}{ Uncalibrated compounds } \\
\hline Boiling point $<100^{\circ} \mathrm{C}$ & 75.5 & 0.36 & 4.4 & 91.3 & 0.94 & 8.5 \\
\hline Boiling point $\geq 100^{\circ} \mathrm{C}$ & 34.2 & 0.26 & 10.5 & 158 & 0.90 & 19.3 \\
\hline \multicolumn{7}{|c|}{ Total concentration of compounds } \\
\hline $\begin{array}{l}\text { Boiling point }<100^{\circ} \mathrm{C} \\
\text { Boiling point } \geq 100^{\circ} \mathrm{C}\end{array}$ & $\begin{array}{l}105 \\
75.5\end{array}$ & $\begin{array}{l}0.74 \\
1.70\end{array}$ & $\begin{array}{l}5.0 \\
4.9\end{array}$ & $\begin{array}{l}429 \\
334\end{array}$ & $\begin{array}{l}2.37 \\
4.98\end{array}$ & $\begin{array}{l}9.4 \\
9.6\end{array}$ \\
\hline Total concentration & 149 & 2.50 & 5.0 & 649 & 7.74 & 9.8 \\
\hline
\end{tabular}

other two units (table 4). As is apparent from the table, the time-weighted average of the half-day exposure was significantly less for jet fuel handling than for flight servicing and workshop servicing $(P<0.05)$. In work with both jet fuel and other solvents, the exposure to hydrocarbons was higher than in work with jet fuel only $(\mathrm{P}<0.01)$.

The mean exposure to $n$-hexane and benzene, two compounds with specific toxic properties, was low, the maximum 8-h TWA values being respectively about
16 and $4 \mathrm{mg} / \mathrm{m}^{3}$ and the maximum 15 -min STEL values being about 157 and $39 \mathrm{mg} / \mathrm{m}^{3}$, respectively (table 5). The present Swedish occupational exposure limits for n-hexane are an $8-\mathrm{h}$ TWA of $180 \mathrm{mg} / \mathrm{m}^{3}$ and a 15-min STEL of $250 \mathrm{mg} / \mathrm{m}^{3}$. The corresponding values for benzene are an $8-\mathrm{h}$ TWA of $16 \mathrm{mg} / \mathrm{m}^{3}$ and a 15-min STEL of $30 \mathrm{mg} / \mathrm{m}^{3}$ (7).

The composition of the airborne hydrocarbon mixture derived from MC-77 jet fuel alters with the total concentration. Thus the relative amount of $n$-hexane 
Table 4. Total hydrocarbon exposure $\left(\mathrm{mg} / \mathrm{m}^{3}\right)$ in different aircraft units and during different types of work.

\begin{tabular}{|c|c|c|c|c|c|c|c|c|}
\hline & \multicolumn{4}{|c|}{ Half-day samples } & \multicolumn{4}{|c|}{ Short-time samples } \\
\hline & $\mathrm{N}$ & $\begin{array}{l}\text { Maximum } \\
\text { value }\end{array}$ & $\begin{array}{c}\text { Geometr } \\
\text { mean }\end{array}$ & $\begin{array}{l}\text { Geomet- } \\
\text { ric SD }\end{array}$ & $\mathrm{N}$ & $\begin{array}{l}\text { Maximum } \\
\text { value }\end{array}$ & $\begin{array}{l}\text { Geometric } \\
\text { mean }\end{array}$ & $\begin{array}{l}\text { Geomet- } \\
\text { ric SD }\end{array}$ \\
\hline $\begin{array}{l}\text { Unit A } \\
\text { Unit B } \\
\text { Unit C }\end{array}$ & $\begin{array}{l}40 \\
32 \\
20\end{array}$ & $\begin{array}{r}149 \\
29 \\
135\end{array}$ & $\begin{array}{l}5.3 \\
1.0 \\
2.2\end{array}$ & $\begin{array}{l}4.9 \\
4.0 \\
3.4\end{array}$ & $\begin{array}{l}20 \\
16 \\
10\end{array}$ & $\begin{array}{r}649 \\
74 \\
125\end{array}$ & $\begin{array}{r}16.2 \\
3.3 \\
7.0\end{array}$ & $\begin{array}{r}8.4 \\
9.2 \\
10.9\end{array}$ \\
\hline $\begin{array}{l}\text { Jet fuel handling } \\
\text { Flight service } \\
\text { Workshop service }\end{array}$ & $\begin{array}{l}12 \\
56 \\
24\end{array}$ & $\begin{array}{r}7 \\
135 \\
149\end{array}$ & $\begin{array}{l}0.9 \\
3.3 \\
2.1\end{array}$ & $\begin{array}{l}2.7 \\
5.0 \\
5.3\end{array}$ & $\begin{array}{r}6 \\
28 \\
12\end{array}$ & $\begin{array}{r}48 \\
370 \\
649\end{array}$ & $\begin{array}{l}6.0 \\
9.3 \\
5.8\end{array}$ & $\begin{array}{r}6.9 \\
10.0 \\
12.3\end{array}$ \\
\hline $\begin{array}{l}\text { Pure jet-fuel exposure } \\
\text { Mixed-solvent exposure }\end{array}$ & $\begin{array}{l}82 \\
10\end{array}$ & $\begin{array}{r}149 \\
72\end{array}$ & $\begin{array}{r}2.1 \\
11.7\end{array}$ & $\begin{array}{l}4.7 \\
3.1\end{array}$ & $\begin{array}{r}40 \\
6\end{array}$ & $\begin{array}{l}649 \\
345\end{array}$ & $\begin{array}{c}5.7 \\
59.1\end{array}$ & $\begin{array}{l}9.4 \\
4.0\end{array}$ \\
\hline All samples & 92 & 149 & 2.5 & 5.0 & 46 & 649 & 7.7 & 9.8 \\
\hline
\end{tabular}

Table 5. $\mathrm{n}$-Hexane and benzene in workday (8-h TWA) and short-time (15-min STEL) exposure (mg/m $\left.{ }^{3}\right)$ during the different types of work.

\begin{tabular}{|c|c|c|c|c|c|c|c|c|}
\hline & \multicolumn{4}{|c|}{ 8-h TWA exposure } & \multicolumn{4}{|c|}{ 15-min STEL exposure } \\
\hline & $\mathrm{N}$ & $\begin{array}{l}\text { Maximum } \\
\text { value }\end{array}$ & $\begin{array}{c}\text { Geometri } \\
\text { mean }\end{array}$ & $\begin{array}{l}\text { Geomet- } \\
\text { ric SD }\end{array}$ & $N$ & $\begin{array}{l}\text { Maximum } \\
\text { value }\end{array}$ & $\begin{array}{l}\text { Geometric } \\
\text { mean }\end{array}$ & $\begin{array}{l}\text { Geornet- } \\
\text { ric SD }\end{array}$ \\
\hline \multicolumn{9}{|l|}{ n-Hexane } \\
\hline $\begin{array}{l}\text { Jet fuel handling } \\
\text { Flight service } \\
\text { Workshop service }\end{array}$ & $\begin{array}{r}6 \\
28 \\
12\end{array}$ & $\begin{array}{r}0.1 \\
10.4 \\
16.1\end{array}$ & $\begin{array}{l}0.02 \\
0.09 \\
0.06\end{array}$ & $\begin{array}{r}2.9 \\
7.8 \\
10.8\end{array}$ & $\begin{array}{r}6 \\
28 \\
12\end{array}$ & $\begin{array}{r}0.9 \\
40.8 \\
157.4\end{array}$ & $\begin{array}{l}0.10 \\
0.17 \\
0.23\end{array}$ & $\begin{array}{r}6.9 \\
13.8 \\
21.2\end{array}$ \\
\hline $\begin{array}{l}\text { Pure jet fuel exposure } \\
\text { Mixed solvent exposure }\end{array}$ & $\begin{array}{r}38 \\
8\end{array}$ & $\begin{array}{r}16.1 \\
2.2\end{array}$ & $\begin{array}{l}0.05 \\
0.14\end{array}$ & $\begin{array}{l}8.1 \\
6.3\end{array}$ & $\begin{array}{r}40 \\
6\end{array}$ & $\begin{array}{r}157 \\
5.3\end{array}$ & $\begin{array}{l}0.18 \\
0.12\end{array}$ & $\begin{array}{l}14.1 \\
15.0\end{array}$ \\
\hline All samples & 46 & 16.1 & 0.06 & 7.9 & 46 & 157 & 0.17 & 13.8 \\
\hline \multicolumn{9}{|l|}{ Benzene } \\
\hline $\begin{array}{l}\text { Jet fuel handling } \\
\text { Flight service } \\
\text { Workshop service }\end{array}$ & $\begin{array}{r}6 \\
28 \\
12\end{array}$ & $\begin{array}{l}0.1 \\
1.2 \\
4.1\end{array}$ & $\begin{array}{l}0.03 \\
0.08 \\
0.05\end{array}$ & $\begin{array}{l}2.6 \\
3.6 \\
5.7\end{array}$ & $\begin{array}{r}6 \\
28 \\
12\end{array}$ & $\begin{array}{r}0.2 \\
4.4 \\
39.4\end{array}$ & $\begin{array}{l}0.06 \\
0.18 \\
0.10\end{array}$ & $\begin{array}{r}4.4 \\
5.4 \\
12.8\end{array}$ \\
\hline $\begin{array}{l}\text { Pure jet fuel exposure } \\
\text { Mixed solvent exposure }\end{array}$ & $\begin{array}{r}38 \\
8\end{array}$ & $\begin{array}{l}4.1 \\
0.5\end{array}$ & $\begin{array}{l}0.06 \\
0.11\end{array}$ & $\begin{array}{l}4.2 \\
3.1\end{array}$ & $\begin{array}{r}40 \\
6\end{array}$ & $\begin{array}{r}39.4 \\
0.5\end{array}$ & $\begin{array}{l}0.15 \\
0.10\end{array}$ & $\begin{array}{l}7.0 \\
6.4\end{array}$ \\
\hline All samples & 46 & 4.1 & 0.06 & 4.1 & 46 & 39.4 & 0.14 & 6.8 \\
\hline
\end{tabular}

Table 6. Concentrations of some compounds $\left(\mathrm{C}_{\text {comp }}>0.01 \mathrm{mg} / \mathrm{m}^{3}\right)$ as a function of the total concentration of hydrocarbons $\left(C_{\text {tot }}>1 \mathrm{mg} / \mathrm{m}^{3}\right)$ in jet fuel vapor. $\left[\log _{10}\left(\mathrm{C}_{\text {comp }}\right)=\mathrm{K}^{\mathrm{P}} \log _{10}\left(\mathrm{C}_{\mathrm{tot}}\right)+\mathrm{L}^{\mathrm{a}}\right]$

\begin{tabular}{lccccc}
\hline & $\mathrm{N}$ & $\begin{array}{c}\text { Intercept } \\
\mathrm{L}\end{array}$ & $\begin{array}{c}\text { Slope } \\
\mathrm{K}\end{array}$ & $\begin{array}{c}\text { Standard deviation } \\
\text { of slope }\end{array}$ & $\begin{array}{c}\text { Correlation } \\
\text { coefficient }\end{array}$ \\
\cline { 2 - 6 } $\begin{array}{l}\text { n-Hexane } \\
\text { Benzene }\end{array}$ & 19 & -2.07 & 1.50 & 0.14 & 0.96 \\
Compounds with & 38 & -1.26 & 0.65 & 0.10 & 0.75 \\
boiling point $<100^{\circ} \mathrm{C}$ & 6 & -1.33 & 1.42 & 0.14 & 0.98 \\
All aromatic compounds & 38 & -0.60 & 0.77 & 0.04 & 0.95 \\
\hline
\end{tabular}

a $\mathrm{C}_{\text {comp }}=$ concentration, exceeding $0.01 \mathrm{mg} / \mathrm{m}^{3}$, of each compound, $\mathrm{C}_{\mathrm{tot}}=$ total concentration, exceeding $1 \mathrm{mg} / \mathrm{m}^{3}$, of all hydrocarbons.

and low-boiling compounds increased significantly with an increase in the total hydrocarbon concentration (slope $>1, \mathrm{P}<0.005, \mathrm{P}<0.05$ ), while the relative amount of benzene and aromatic compounds decreased (slope $<1, \mathrm{P}<0.002, \mathrm{P}<0.001$ ) (table 6).

\section{Discussion}

When occupational exposure to air pollutants is being determined, the results obtained depend on the sam- pling strategy used. Ordinary check-up measurements are usually not performed to permit estimation of the long-term exposure. As a rule, the bias is probably positive, ie, the exposure is overrated (13). In this study, both the measuring periods and examined persons were selected in an arbitrary way so that the outcome would present an unbiased and representative picture of the exposure situation.

The results indicate that, today, the average longterm exposure to jet fuel in Swedish aircraft units is low $\left(1-5 \mathrm{mg} / \mathrm{m}^{3}\right)$. However, infrequent peak expo- 
sures in the range of $100-1000 \mathrm{mg} / \mathrm{m}^{3}$ sometimes occur during specific work operations such as the dismantling of fuel systems, the cleaning of fuel supply tanks, and the removal of engines from aircraft. These work operations occur sporadically, and the exposure risks are well known among the employees. Most of these work operations are planned in advance and are possible to predict. Therefore, it seems probable that the short-time measurements performed roughly reflect the present frequency of peak exposures to jet fuel vapors in the Swedish Armed Forces.

The jet fuel handling group had the lowest exposure. None of the daily mean exposures exceeded $10 \%$ of the present 8-h TWA limit, and none of the peak exposures exceeded $10 \%$ of the present 15 -min STEL. This result might depend on the fact that most of this work is done outdoors. As a rule, the hydrocarbon exposure is low in similar situations when volatile fuels are handled outdoors, eg, when filling tank trucks with gasoline from storage tanks (10).

Indoor work for the jet fuel handling group mainly consisted of pump service. Measurements of jet fuel exposure in different Swedish aircraft units during 1975-1982 have primarily been focused on this work, and total hydrocarbon concentrations of 5-1 165 $\mathrm{mg} / \mathrm{m}^{3}$ in grab samples and $26-620 \mathrm{mg} / \mathrm{m}^{3}$ in 1 -h exposure samples have been registered according to the unpublished results of L Rittfelt \& G Svensson. The situation has continuously been improved by an increase in the general ventilation and the installation of local exhausts. Measurements performed in 1982 (unpublished results of G. Svensson) and 1984 (unpublished results of G Lind) during 38-225 min of pump service work showed exposure levels in the range of $65-230 \mathrm{mg} / \mathrm{m}^{3}$.

The service personnel group constitutes a large proportion $(60-70 \%)$ of the personnel exposed to jet fuel in an aircraft unit. This group mainly works indoors in hangars with general ventilation of different efficiency, but it also works outdoors on the runway when the aircraft are refueled. Although the mean long-term exposure for this group was found to be low $\left(3 \mathrm{mg} / \mathrm{m}^{3}\right)$, two events with high peak exposures ( 345 and $370 \mathrm{mg} / \mathrm{m}^{3}$ ) were observed. In one of these cases, however, the source of exposure was not jet fuel, but the white spirit used in manual cleaning work.

Although the service personnel is the largest occupational group exposed to jet fuel in Swedish aircraft units, there are few other measurements available. In an unpublished study performed by L Rittfelt in 1975, a grab sample of the air in a hangar showed a total hydrocarbon concentration of 56 $\mathrm{mg} / \mathrm{m}^{3}$. Measurements from 1984 showed peak exposures in the range of $16-140 \mathrm{mg} / \mathrm{m}^{3}$ according to unpublished results of $G$ Lind. These measurements were performed during $4 \mathrm{~h}$ of simulated work.

Workshop service personnel mainly work indoors, partly doing jobs similar to those of the flight service personnel. This group also has specific tasks which could result in jet fuel exposure, such as the servicing of dismantled jet motors. As for the other groups, the long-term exposure was low $\left(2 \mathrm{mg} / \mathrm{m}^{3}\right)$, with infrequent high-peak exposures. However, in this group the only short-time exposure exceeding the present 15-min STEL for jet fuel was observed. This single peak exposure $\left(649 \mathrm{mg} / \mathrm{m}^{3}\right)$ was due to jet fuel leakage inside an aircraft as the fuel tubes were disconnected after removal of a jet motor.

Earlier check-up measurements have mainly been focused on jet fuel exposure in the motor workshops. Some samples from the breathing zones of motor workshop personnel have shown incidental peak exposures in the range of $192-450 \mathrm{mg} / \mathrm{m}^{3}$ (L Rittfelt, unpublished results).

Exposure data from employees testing new jet motors in an aircraft factory demonstrated almost daily exposures in the range of $45-212 \mathrm{mg} / \mathrm{m}^{3}$ (3). Obviously, the exposure conditions in the motor workshop of the factory were different from those in the aircraft units.

During $11 \%$ of the half-day and $15 \%$ of the shorttime sampling periods, the work involved jet fuel exposure combined with exposure to white spirit and other solvents in paints. Exposure to isopropyl nitrate occurred in only one of the half-day sampling periods $(1 \%)$. During periods with mixed-solvent exposure, the mean hydrocarbon concentrations in the respiratory zones were considerably higher than the mean concentrations occurring during periods with pure jet fuel exposure. This finding indicates a significant contribution to the total exposure of hydrocarbons from sources other than jet fuel.

During the investigation only two episodes with skin contact to jet fuel and one episode with skin contact to isopropyl nitrate were observed. Thus skin contact with jet fuel seems to be a rare phenomenon nowadays. A dominant opinion expressed by the squadrons was also that skin contact to jet fuel used to be more common earlier.

There are no reports available on the percutaneous absorption of jet fuel, but some of the components have been studied. Engström et al (1) found a percutaneous absorption rate of $2 \mu \mathrm{g} \cdot \mathrm{cm}^{-2} \cdot \mathrm{min}^{-1}$ for $\mathrm{m}$-xylene in humans when hands were immersed in the solvent. In a similar study, the dermal absorption of gasoline was found to be $2-10 \mu \mathrm{g} \cdot \mathrm{cm}^{-2} \cdot \mathrm{min}^{-1}$ (8). Gasoline has a lower boiling range than jet fuel.

Tsuruta (12) performed an in vitro study on the permeability of various nonpolar hydrocarbons through rat skin and found a correlation between the permeability and water solubility of the different compounds. The highest permeation rates were found for the most water-soluble hydrocarbons, benzene and toluene. The higher aliphatic hydrocarbons dominating in jet fuel were less soluble in water. Thus skin absorption seems to be a minor problem for personnel groups exposed to jet fuel. 
Nowadays, the exposure pattern for all personnel groups in the Swedish Armed Forces is characterized by a low background exposure and infrequent peak exposures to jet fuel vapor. This exposure pattern is a function of the basic organization of the work in the squadrons, which has been almost unchanged since jet fuel was introduced in 1956. However, during the last decade both the frequency of peak exposures and the mean exposure to jet fuel vapor have diminished due to the introduction of new types of aircraft, improvements in general ventilation, the introduction of closed refueling systems, and the increasing use of local exhausts during specific work operations. An increased awareness among the employees has also resulted in less skin contact and a reduced spill of fuel.

\section{References}

1. Engström K, Husman K, Riihimäki V. Percutaneous absorption of m-xylene in man. Int Arch Occup Environ Health 39 (1977) 181-189.

2. Flodin U, Edling C, Axelson O. Clinical studies of psychoorganic syndrome among workers with exposure to solvents. Am J Ind Med 5 (1984) 287-295.

3. Knave B, Anshelm-Olson B, Elof sson S, Gamberale F, Isaksson A, Mindus P, Persson HE, Struwe G, Wennberg A, Westerholm P. Long-term exposure to jet fuel: II A cross-sectional epidemiologic investigation on occupationally exposed industrial workers with special reference to the nervous system. Scand J Work Environ Health 4 (1978) 19-45.
4. Knave B, Mindus P, Struwe G. Neurasthenic symptoms in workers occupationally exposed to jet fuel. Acta Psychiatr Scand 60 (1979) 39-49.

5. Knave B, Persson HE, Goldberg JM, Westerholm P. Long-term exposure to jet fuel: An investigation on occupationally exposed workers with special reference to the nervous system. Scand J Work Environ Health 2 (1976) 152-164.

6. Leidel NA, Busch KA, Lynch JR. Occupational exposure sampling strategy manual. Department of Health Education and Welfare, Cincinnati, OH 1977. (DHEW Publ (NIOSH) (1977) 77-173).

7. National Board of Occupational Safety and Health. Code of Statutes. Stockholm 1984. (AFS 1984: 5).

8. Oettel H. Wirkung auf die unverletzte menschliches Haut. Schilderung der einzelnen Substanzgruppen: Aliphatische Kohlenwasserstoffe. Naunyn Schmiedebergs Arch Exp Pathol Pharmakol 183 (1936) 649-652.

9. Owen DB. Handbook of statistical tables. Pergamon Press, London 1962.

10. Philips CF, Jones RK. Gasoline vapour exposure during bulk handling operations. Am Ind Hyg Assoc J 39 (1978) $118-128$.

11. Struwe G, Knave B, Mindus P. Neuropsychiatric symptoms in workers occupationally exposed to jet fuel A combined epidemiological and casuistic study. Acta Psychiatr Scand Suppl 303 (1983) 55-67.

12. Tsuruta H. Percutaneous absorption of organic solvents: III On the penetration of hydrophobic solvents through the excised rat skin. Ind Health 20 (1982) 335-345.

13. Ulfvarson U. Limitations to the use of employee exposure data on air contaminants in epidemiologic studies. Int Arch Occup Environ Health 52 (1983) 285-300.

Received for publication: 31 March 1987 